\title{
Unlocking bone for proteomic analysis and FISH
}

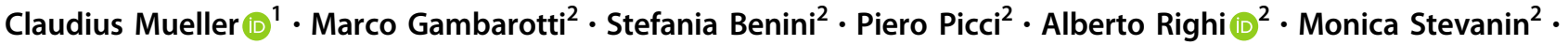 \\ Sabine Hombach-Klonisch ${ }^{3} \cdot$ Dana Henderson $^{3} \cdot$ Lance Liotta $^{1} \cdot$ Virginia Espina ${ }^{1}$
}

Received: 18 January 2018 / Revised: 4 September 2018 / Accepted: 14 September 2018 / Published online: 18 January 2019

(c) United States \& Canadian Academy of Pathology 2019

\begin{abstract}
Bone tissue is critically lagging behind soft tissues and biofluids in our effort to advance precision medicine. The main challenges have been accessibility and the requirement for deleterious decalcification processes that impact the fidelity of diagnostic histomorphology and hinder downstream analyses such as fluorescence in-situ hybridization (FISH). We have developed an alternative fixation chemistry that simultaneously fixes and decalcifies bone tissue. We compared tissue morphology, immunohistochemistry (IHC), cell signal phosphoprotein analysis, and FISH in 50 patient matched primary bone cancer cases that were either formalin fixed and decalcified, or theralin fixed with and without decalcification. Use of theralin improved tissue histomorphology, whereas overall IHC was comparable to formalin fixed, decalcified samples. Theralin-fixed samples showed a significant increase in protein and DNA extractability, supporting technologies such as laser-capture microdissection and reverse phase protein microarrays. Formalin-fixed bone samples suffered from a fixation artifact where protein quantification of $\beta$-actin directly correlated with fixation time. Theralin-fixed samples were not affected by this artifact. Moreover, theralin fixation enabled standard FISH staining in bone cancer samples, whereas no FISH staining was observed in formalin-fixed samples. We conclude that the use of theralin fixation unlocks the molecular archive within bone tissue allowing bone to enter the standard tissue analysis pipeline. This will have significant implications for bone cancer patients, in whom personalized medicine has yet to be implemented.
\end{abstract}

\section{Introduction}

In recent years, bone has stepped out of its typical functional niche as the skeletal framework and site for hematopoiesis. Multiple hormones originate from bone that regulate glucose homeostasis, energy expenditure, phosphate metabolism, and food intake. This extends its function to that of a complex pleiotropic endocrine organ, which

Supplementary information The online version of this article (https:// doi.org/10.1038/s41374-018-0168-7) contains supplementary material, which is available to authorized users.

$\triangle$ Lance Liotta

lliotta@gmu.edu

1 Center for Applied Proteomics and Molecular Medicine, George Mason University, Manassas, VA, USA

2 Department of Pathology, IRCCS, Istituto Ortopedico Rizzoli, Bologna, Italy

3 Department of Human Anatomy and Cell Science, Rady Faculty of Health Sciences, University of Manitoba, Manitoba, Winnipeg, Canada communicates with cells in diverse organs such as the brain, kidneys, and pancreas [1-4]. Bone is also at the core of diseases such as cancer, where more than one third of cancer patients that die each year show bone metastases [5]. In fact, bone is a primary metastatic site for breast cancer, the second most common cancer worldwide [6]. It is therefore critical to unlock the molecular archive of bone tissue for in-depth molecular and standard clinical histology analysis. Nonetheless, bone remains one of the most difficult tissues to evaluate and treat owing to challenging biopsy procedures and its calcified matrix, which requires demineralization prior to regular clinical laboratory processing. Different decalcification strategies have been developed, including solubilizing calcium with acid, chelating calcium with ethylenediaminetetraacetic acid (EDTA), cation ion exchange resins, or ammonium phosphate and ammonium bicarbonate extraction [7-14]. Depending on the decalcification strategy chosen, different undesirable artifacts, such as the destruction of nucleic acids and protein epitopes, severely limit downstream analysis $[15,16]$. In fact, standard of care diagnostics, such as fluorescence in-situ hybridization (FISH), are prohibited in bone tissue. 
Advancing precision medicine in cancer requires the tissue-specific analysis of low abundance and labile biomarkers, such as phosphorylated proteins, in individual patients. Owing to the fact that a large percentage of current lead compounds for targeted cancer therapy are protein kinase inhibitors [17], quantification of cell signaling proteins in soft tissue tumors is becoming increasingly important. But bone tissue is sidelined in the advancement of personalized medicine because of its inaccessibility for standard proteomic and genomic downstream analysis.

It is known that a significant percentage of primary breast tumors and their metastases show discordance in their estrogen, progesterone, and HER2 receptor status [18]. Unfortunately, patients with a HER2 negative primary breast tumor and HER2 positive bone metastasis are never identified because HER2 FISH assays will not work after standard decalcification and formalin fixation. Since HER2 FISH is the clinical gold standard for determining eligibility for HER2 therapy, these patients can never benefit from standard of care therapy.

We developed theralin, a single-step, room temperature tissue preservative that is compatible with paraffin embedding and standard clinical and research downstream analysis methods such as immunohistochemistry (IHC) [19]. Theralin is a precipitating fixative that contains: (i) permeation enhancers that decrease the tissue penetration rate, (ii) reversible cross-linkers that stably cross-link biomolecules during tissue preservation while allowing full biomolecule recovery during extraction, (iii) kinase and phosphatase inhibitors that prohibit ex vivo alterations of protein phosphorylation, and (iv) an osmotically balanced buffer and a carboxylic acid that maintain tissue morphology during the fixation process. This tissue fixative solves the problem of rapid biomarker preservation at room temperature while maintaining tissue histomorphology and antigenicity in soft tissues. Here, we set out to study if this same tissue preservation chemistry could be applied to bone tissue. Owing to our serendipitous discovery that theralin decalcifies bone, we wanted to determine whether theralin could simultaneously retain labile protein biomarkers and tissue morphology while solubilizing the calcified matrix. This would obviate the need for a separate demineralization step and possibly enable rigorous and standardized diagnostic assays such as FISH that were previously hindered by standard formalin fixation coupled with decalcification of bone tissues.

\section{Materials and methods}

\section{Sample collection}

Fifety biopsies, performed between February and June 2011 at the Rizzoli Orthopedic Institute, Bologna, Italy, were collected and the bone-containing material divided into six $1 \times 0.5 \times 0.5 \mathrm{~cm}$ blocks. Tissue blocks were processed in parallel according to the following protocols: (1) fixation with theralin, (2) fixation with theralin, followed by standard decalcification, and (3) fixation with formalin, followed by standard decalcification. Samples were fixed in 6-7 $\mathrm{ml}$ of fixative (either theralin or $4 \%$ neutral-buffered formalin $(\mathrm{NBF})$ at room temperature for $24-48 \mathrm{~h}$. Decalcification was performed using a mixture of $5.1 \%$ formic acid and $2.5 \%$ nitric acid. The time of decalcification varied between samples depending on bone content and was determined by palpation, a commonly used method for decalcification endpoint determination in clinical pathology laboratories [20] and established standard method at the Rizzoli Orthopedic Institute, Bologna, Italy, where all clinical samples were collected. Two blocks for each method were processed in parallel with one block being evaluated at the Rizzoli Institute, Italy, (clinical IHC, FISH) and a matching block evaluated at George Mason University, Fairfax, USA, (laser capture microdissection (LCM), reverse phase protein microarrays (RPPA), IHC) or the University of Manitoba, Canada (telomere FISH), resulting in a total of 300 tissue blocks available for this study.

Control samples for FISH analysis: human tibia, procured following an amputation, and Balb/c mouse (Envigo, Indianapolis, IN, USA) ribs were fixed for 7-14 days in either theralin or $10 \%$ NBF. Formalin-fixed samples were decalcified in formic acid for 24-48 h.

Control samples for correlation of $\beta$-actin reactivity with fixation time: U266 cells were grown to $80 \%$ confluence and incubated in serum-free media overnight. Following, cells were either lysed directly or fixed with theralin or $10 \%$ $\mathrm{NBF}$ for $10 \mathrm{~min}$ and $2 \mathrm{~h}$ before lysis. Liver samples from three ICR (CD-1) mice (Envigo, Indianapolis, IN, USA) were fixed for 1 day or 7 days in either theralin or $10 \%$ neutral buffered formalin. $\beta$-actin levels were quantified using RPPA (see below).

Mice were housed according to standard animal care procedures with water and chow provided ad libitum and killed with $\mathrm{CO}_{2}$. Animal studies were carried out in strict accordance with the recommendations in the Guide for the Care and Use of Laboratory Animals of the National Institutes of Health and the protocol was approved by the George Mason University institutional animal care and use committee. All animal tissue samples were taken as a terminal event post euthanasia, and all efforts were made to minimize suffering. Human surgical tissue specimens were collected from patients under written informed consent following the protocols by the Rizzoli Orthopedic Institute (samples 1-50, Supplemental Table 1) or the institutional review boards of Inova Fairfax Hospital and George Mason University (sample 51). 


\section{FISH}

FISH was performed at two locations, using different protocols. At the Rizzoli Orthopedic Institute, FISH was performed using the LSI FOXO1 Dual Color Break-apart DNA probe (13q14) (Abbott Molecular, Des Plaines, IL, USA) and the SPEC MDM2/CEN 12 Dual Color probe (12q14.312q15) (ZytoVision GmbH, Bremerhaven, Germany) according to the manufacturer's protocol. Tissue sections of $4 \mu \mathrm{m}$ were mounted on positively charged slides (Dako, Glostrup, Denmark). Slides were heated overnight $\left(60^{\circ} \mathrm{C}\right)$, dewaxed in xylene, and treated with an ethanol-to-water series. This was followed by incubation in TE solution (TRIS $5 \mathrm{~mm}$-EDTA $1 \mathrm{~mm}$ ) at $96^{\circ} \mathrm{C}$ for $15 \mathrm{~min}$, rinsed in distilled water, and digested with pepsin $(0.04 \%)$ in $0.01 \mathrm{~N}$ $\mathrm{HCl}$ at $37^{\circ} \mathrm{C}$ for $5-15 \mathrm{~min}$, then washed again in distilled water. Slides were finally dehydrated in ethanol (96\%) and air dried. Next, the probes were applied to the target area and the slides were coverslipped and sealed with rubber cement. The samples and probes were co-denaturated in Dako Hybridizer (Dako, Glostrup, Denmark) at $85^{\circ} \mathrm{C}$ for 1 min and incubated overnight at $37^{\circ} \mathrm{C}$. The following day, the coverslips were removed and the slides were washed 2 $\min$ at $73{ }^{\circ} \mathrm{C}$ in $0.4 \times \mathrm{SSC} / 0.3 \% \mathrm{NP} 40$ and $1 \mathrm{~min}$ at room temperature in $2 \times \mathrm{SSC} / 0.1 \% \mathrm{NP} 40$. The slides were then left to dry in the dark at room temperature; the nuclei were subsequently counterstained in Vectashield Antifade solution with 4,6-diamino-2-phenylindole (DAPI) (Vector Laboratories, Inc. Burlingame CA, USA). Fluorescence signals were counted using an OLYMPUS BX41 fluorescence microscope (Olympus, Hamburg Germany), at 100× under oil immersion using an appropriate filter set. A minimum of 100 tumor cell nuclei with intact morphology, as determined by DAPI counterstaining, were counted in the previously marked neoplastic area. A positive result was defined as the presence of a visible red and green signals in $>10 \%$ of the cells.

At the University of Manitoba, slides were deparaffinized and dehydrated in $100 \%$ ethanol, then incubated in $1 \mathrm{M}$ $\mathrm{NaSCN}$ for $30 \mathrm{~min}$ at $80{ }^{\circ} \mathrm{C}$ in a water bath. After rinse in double-distilled water, slides were incubated in $3.7 \%$ buffered formalin solution (Sigma-Aldrich, Oakville, ON, Canada) in $2 \times \mathrm{SSC}$ buffer (pH 7.6) for $10 \mathrm{~min}$ at room teperature (RT) and washed two times in $2 \times \mathrm{SSC}$ for $5 \mathrm{~min}$ each. Totally $50 \mu \mathrm{g} / \mathrm{ml}$ pepsin was added to $0.01 \mathrm{M} 37^{\circ} \mathrm{C}$ prewarmed HCL and slides were incubated for $6 \mathrm{~min}$ followed by two washes in $2 \times \mathrm{SSC}$ for $5 \mathrm{~min}$ each. After exposure to $3.7 \%$ buffered formalin solution (SigmaAldrich, Oakville, ON, Canada) in $2 \times$ SSC buffer (pH 7.6) for $10 \mathrm{~min}$ at RT and two washes in $2 \times \mathrm{SSC}$, tissues were dehydrated in ethanol. In total, $5 \mu$ of $\mathrm{Cy} 3$-labeled peptide nucleic acid telomere (PNA) probe (Dako, Glostrup,Denmark) was applied to each slide to detect (T2AG3)n repeats.
Slides and probe were incubated at $80^{\circ} \mathrm{C}$ for $3 \mathrm{~min}$ to denature DNA, followed by hybridization at $30^{\circ} \mathrm{C}$ for $2 \mathrm{~h}$ using the Hybrite chamber (Vysis, Abbott Diagnostics Mississauga, ON, Canada). Next, slides were washed twice in $70 \%$ formamide in $10 \mathrm{~mm}$ Tris ( $\mathrm{pH} \mathrm{7.4)} \mathrm{followed} \mathrm{by}$ successive washings in phosphate-buffered saline at RT for $1 \mathrm{~min}$, in $0.13 \mathrm{SSC}$ at $55^{\circ} \mathrm{C}$ for $5 \mathrm{~min}$ and in $2 \times \mathrm{SSC}$ in $0.05 \%$ Tween 20 twice at RT. Slides were counterstained with DAPI (Invitrogen, Burlington, ON, Canada) $(0.1 \mu \mathrm{l} /$ $\mathrm{ml}$ ), washed in doubled distilled water and dehydrated in ethanol. Before imaging, slides were mounted to coverslips using Vestashield antifade mounting medium (Vector Laboratories, Burlington, ON, Canada).

Fluorescent images were captured using the AxioImager Z1 microscope, an AxioCamMR3 camera and a PlanApochromat $\times 63 / 1.40$ Oil DIC M27 lens (all from Carl Zeiss, Canada). Acquisition time was $300 \mathrm{msec}$ for $\mathrm{Cy} 3$ (telomeres signals) and $100 \mathrm{msec}$ for DAPI. For each nucleus, images were acquired from 60 optical planes (z-stacks) through the nucleus with a sampling distance in the $x y$ axis of $107 \mathrm{~nm}$ and $z$ axis of $200 \mathrm{~nm}$ using ZEN 2 blue edition software (Carl Zeiss, Canada). Images were deconvolved using a constrained iterative algorithm (Schaefer et al., 2001) available in the ZEN software (Zeiss).

\section{LCM}

Tissue was cut into $8 \mu \mathrm{m}$ sections and LCM conducted as previously described [21]. Care was taken to selectively microdissect tumor cells without inclusion of necrotic tissue, blood vessels, body fluids, bone matrix, and normal bone cells. Cells were microdissected from seven representative cases based on comparable cell content across all three fixation types: one chordoma, three giant cell tumors, one bone metastasis from carcinoma, one bone metastasis from melanoma, and one aneurysmal bone cyst. Microdissected tissue was lysed using an extraction buffer made of a $10 \%(\mathrm{v} / \mathrm{v})$ solution of Tris(2-carboxyethyl)phosphine (TCEP; Pierce, Rockford, IL) in Tissue Protein Extraction Reagent (T-PERTM, Pierce)/2× SDS Tris-glycine buffer (Invitrogen, Carlsbad, CA). Extraction buffer was added to LCM caps and boiled for $10 \mathrm{~min}$, followed by manual flushing of LCM caps with extraction buffer for $1 \mathrm{~min}$ and another incubation of the extraction buffer alone at $100{ }^{\circ} \mathrm{C}$ for $10 \mathrm{~min}$. Lysed samples were kept at $-80^{\circ} \mathrm{C}$ until printing.

\section{RPPA construction and staining}

RPPA were printed and stained as previously described [22]. Following printing of the lysates, slides were stored dessicated at $-20{ }^{\circ} \mathrm{C}$ before staining. All antibodies used 
(Supplemental Table 2) were extensively validated for a specific band at the appropriate molecular weight by Western blotting prior to their use for RPPA. Raw spot analysis was performed using ImageQuant 5.2 (Molecular Dynamics), followed by postprocessing using the RPPA Analysis Suite (developed in-house [23]).

\section{IHC}

At George Mason University, tissue sections were baked at $56^{\circ} \mathrm{C}$ for $30 \mathrm{~min}$ and deparaffinized in xylene with rehydration in a series of graded alcohols $(100,95,70 \%)$ with a final rinse in water. Following the appropriate heat-induced epitope retrieval per antibody (Supplemental Table 2), slides were stained in a Dako Autostainer using the EnvisionSystem + HRP staining kit (Dako). Nuclear counterstaining was performed using hematoxylin (Sigma-Aldrich, St. Louis, MO, USA) and Scott's Tap Water Substitue (Electron Microscopy Services, Hatfield, PA, USA).

At the Rizzoli Institute, $4 \mu \mathrm{m}$-thick tissue sections were cut, heated at $58^{\circ} \mathrm{C}$ for $2 \mathrm{~h}$, deparaffinised and immunostained on a Ventana BenchMark following the manufacturer's guidelines (Ventana Medical Systems, Tucson AZ, USA). Antibody detection was performed using UltraView Universal DAB Detection Kit (Ventana Medical Systems, Tucson AZ, USA). Pretreatment for antigen retrieval was performed at $95{ }^{\circ} \mathrm{C}$ with Tris-EDTA $\mathrm{pH} 8$ for $20 \mathrm{~min}$. When necessary, endogenous tissue peroxidase was blocked by treating the sections with $0.3 \% \mathrm{H}_{2} \mathrm{O}_{2}$. The slides were stained with hematoxylin and then rehydrated and coverslipped. Appropriate positive and negative controls were included in each run. For antibodies used and respective dilutions, see Supplemental Table (Supplemental Table 2).

\section{Tissue scores and statistical analysis}

Tissue morphology was scored by clinical pathologists based on nuclear and bone detail (excellent, good, moderate, poor) according to the following criteria. Nuclear details ranged from excellent (very well stained nuclei with visible chromatin detail) to poor (poorly defined chromatin detail or over-decalicified "pink-stained" simil-necrotic nuclei). Bone evaluation ranged from excellent (very well stained bone matrix with clearly visible osteoblasts and osteoclasts) to poor ("blue"-stained poorly decalcified bone matrix or over-decalcified bone with "pink-stained" similnecrotic nuclei of the osteoblasts and osteoclasts).

Immunohistochemical stains were scored by pathologists as not evaluable $(\mathrm{NV})$, negative (neg), weak $(1+)$, moderate $(2+)$, and strong $(3+)$, according to the number of positive mononuclear cells and their intensity, with respective threshold values of $<5,5-20$, and $>20 \%$.
Two-way unsupervised hierarchical clustering analysis was prepared using R [24]. Mean comparisons of proteins levels and protein phosphorylation were conducted using Wilcoxon rank-sum or Student's $t$ test, depending on data normality (Shapiro-Wilk test). Data correlation $\left(R^{2}\right)$ was determined using GraphPad Prism (version 6.05, GraphPad Software Inc.), which was also used to prepare all of the bar graphs, box plots, and scatter plots. A $p<0.05$ was chosen to indicate significance.

\section{Results}

\section{Effect of theralin fixation on sample processing time}

Owing to reduced bony matrix content, 6 of the 50 samples $(12 \%)$ did not require decalcification. All remaining formalin-fixed samples were decalcified prior to sectioning. Fixation with theralin obviated the need for a separate decalcification step. Four samples $(9 \%)$ were found to be under-decalcified following fixation with theralin. This did not correlate with fixation time or any potential underlying clinical/pathological feature. Moreover, the tissue morphology was scored equal to or better than patient matched samples that were formalin fixed and decalcified for all four samples. Of the samples that required decalcification after formalin fixation, exact fixation/decalcification times were recorded for 19 samples (43\% of total of 44), ranging from 6.5 to $45 \mathrm{~h}$ per sample for theralin fixed and $18.5-112 \mathrm{~h}$ per sample for formalin-fixed samples. Overall, processing times were decreased by $0-96 \mathrm{~h}$ per sample (median $9.0 \mathrm{~h}$, average $22.6 \mathrm{~h}$ ) for theralin-fixed bone tissue compared with formalin-fixed tissue (Fig. 1a).

As demonstrated, the carboxylic acid component in theralin is therefore able to decalcify bone simultaneously with tissue fixation. This obviated the need for a separate tissue processing step for decalcification, significantly decreasing the overall processing time.

\section{Effect of theralin fixation on clinical histomorphology}

Of the 50 cases, 48 were evaluated by pathologists for adequate preservation of morphology and graded as excellent, good, moderate, and poor based on semiquantitative evaluation of nuclear detail and bone (nuclear and chromatin detail, bone matrix staining, and clearly identifiable osteoblasts and osteoclasts). Of these, 22 cases (46\%) demonstrated better quality morphology after theralin fixation without decalcification, $4(8 \%)$ showed better morphology after NBF fixation with downstream decalcification, and $22(46 \%)$ cases had equal quality morphology between both preservation treatments (Fig. 1b). 


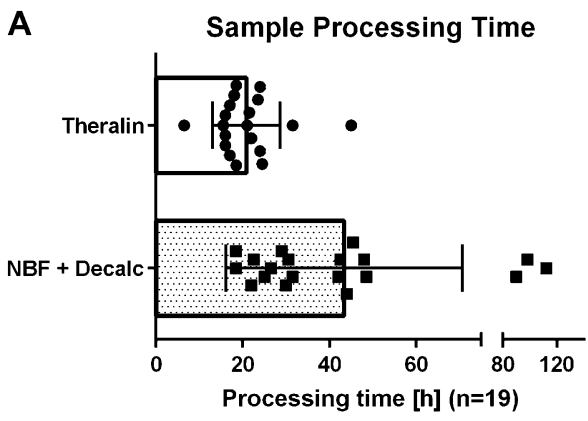

Fig. 1 Theralin fixation obviates the need for bone tissue decalcification and provides better clinical histomorphology. a Sample processing time of 19 bone tumor samples fixed in theralin compared wityh standard formalin fixation combined with decalcification. Processing

The factors that contributed towards the improved morphology after NBF fixation in these four samples are unclear, since the four samples did not overlap with the under-decalcified samples after theralin fixation, did not belong to a single disease type (osteosarcoma (2), osteochondroma (1), bone metastasis from melanoma (1)), and had different decalcification requirements following for-

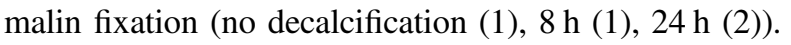

\section{Comparison of immunohistochemical stains between theralin and formalin-fixed bone tissue}

As part of the routine clinical diagnostic workflow, 17 different immunohistochemical stains were performed depending on the diagnostic requirements for each case, resulting in a total of 192 stained sections. To increase robustness of the analysis we limited the data to proteins that were stained in more than two cases, which reduced the total number of stained sections to 125 . IHC stains were scored by pathologists according to the number of positive mononuclear cells and their intensity, with respective threshold values of $<5,5-20$, and $>20 \%$. The majority of IHC stains was scored to be of equal quality, with six proteins showing more cases with better IHC stains after theralin fixation (CD68, Osterix, Brachi, Sox9, P-GP C494, P-GP JSP1) and four proteins with more cases with better IHC stains following fixation with formalin and decalcification (Vimentin, EMA, S100, P-GP MRK16) (Fig. 2). Overall, the relative combined IHC score for both fixation methods was equal in $65 \%$, better for theralin in $19 \%$ and better for formalin with decalcification in $16 \%$.

We also performed additional immunostains for phosphoproteins (ERK Thr202/Tyr204, CREB Ser133, PTEN Ser 380, Acetyl-Co Carboxylase Ser79) and other tumor relevant protein targets (Progesterone receptor, Hifla, Ki67, LC3B) on selected cases (Fig. 3). Although phosphoprotein stains were comparable between theralin-fixed and formalin-fixed tissue samples, no immunostain was visible

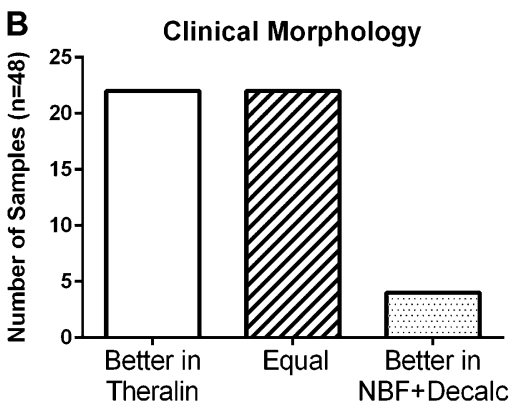

time includes fixation and decalcification (if applied). b Overall scores of tissue morphology following either theralin fixation without decalcification or standard formalin fixation with decalcification. $(\mathrm{NBF}=$ neutral buffered formalin)

in formalin-fixed, decalcified tissue for Ki-67. This was in agreement with the clinical immunostains performed at the Rizzoli Institute, where two cases were positively scored for Ki-67 after theralin fixation, but only one of the cases was positive after standard processing in formalin. Anecdotally, we also had one case with positive progesterone receptor staining after theralin fixation, with no staining after formalin fixation.

\section{Protein and DNA extractability}

To evaluate the feasibility of profiling cancer cell-specific signal proteins in fixed bone samples, we performed tumor cell enrichment by LCM on seven cases. Cases were chosen to represent different tumor types and ensure equal quality tumor cell material for microdissection in patient matched samples per fixation type. It is well known that formalin-fixed tissue requires extended high-temperature protein extraction methods for adequate protein yield [19, 25]. However, owing to the limited lysis volume per LCM cap $(\sim 3-7 \mu \mathrm{l})$, boiling for $1 \mathrm{~h}$ or more is not feasible. To increase protein yield we used an adapted protocol in which the microdissected tissue was heated at $100{ }^{\circ} \mathrm{C}$ for $20 \mathrm{~min}$ in SDS/TCEP extraction buffer $[19,26]$. The total amount of protein that was extractable per microdissected area was doubled following theralin fixation ( 2.2 fold) or following theralin fixation with downstream decalcification (1.9-fold) compared with formalin fixation with decalcification (Fig. 4).

DNA can be used for assay normalization to account for data variances. Proteomic analyses, such as RPPA or western blotting, require data normalization to an invariant entity. Erythrocytes contribute total protein content to a lysate, which can skew total protein levels. However, erythrocytes are devoid of a nucleus and therefore lack nuclear DNA, which allows us to use DNA for normalization when samples such as bone marrow aspirates are contaminated with blood [23]. Furthermore, DNA provides molecular information as well as having utility in data analysis. To 
Fig. 2 Overall

immunohistochemistry scores are comparable. Pathologist scores of IHC stains from patient matched theralin fixed and formalin fixed, decalcified bone tumor samples

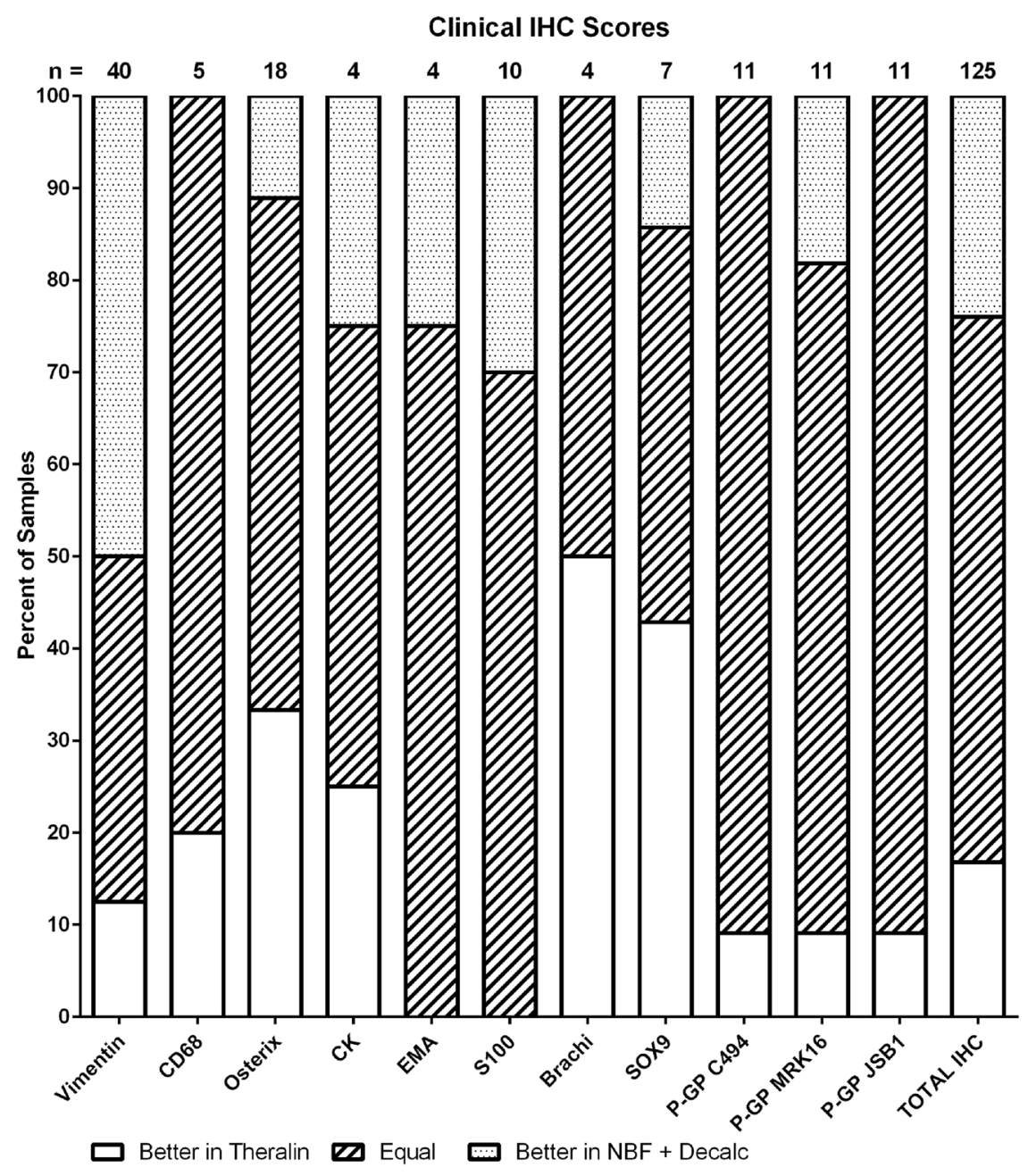

enable molecular profiling of bony tissues, including FISH, we needed to verify that DNA yield was adequate. Therefore, we also compared the amount of measurable DNA per microdissected area in theralin and formalin-fixed bone samples. We found a 2.8-fold increase in DNA in theralinfixed samples and 2.7-fold increase in theralin fixed, decalcified samples, compared with formalin fixed, decalcified samples (Fig. 4). It is important to point out that we did not specifically extract DNA from samples using established nucleic acid isolation protocols but rather printed whole cell lysates onto nitrocellulose slides [22]. The DNA per sample was then denatured and permanently cross-linked to the nitrocellulose as previously described [23]. This approach is critical to enable normalization of RPPA data with DNA content per sample.

To evaluate whether the reduced protein yield from formalin fixed and decalcified samples was selective for specific classes of proteins, we then quantified 46 individual protein endpoints that represent receptor tyrosine kinases, intracellular kinases (phosphorylated and non-phosphorylated), hormone receptors, cytoskeletal proteins, and cleaved caspases. Of these proteins, 21 showed a significantly reduced level in formalin-fixed, decalcified samples compared with matched theralin-fixed, non-decalcified, or decalcified samples (Fig. 5). This reduction in protein yield appeared to be independent of the class of protein evaluated. No significant differences were found between decalcified and non-decalcified theralin-fixed tissue.

\section{Comparable relative protein abundance}

We then evaluated if the fixation process changes protein phosphorylation. To adjust for the reduced protein extractability from formalin-fixed samples, we normalized all protein levels to the total protein amount extracted from each sample. With the exception of $\beta$-actin and Doublecortin, the abundance of all 46 phosphorylated and nonphosphorylated proteins showed no significant difference between theralin and formalin-fixed bone tissue samples. However, following unsupervised two-way hierarchical clustering, formalin-fixed bone samples clustered separately from their respective matched theralin-fixed samples in five 

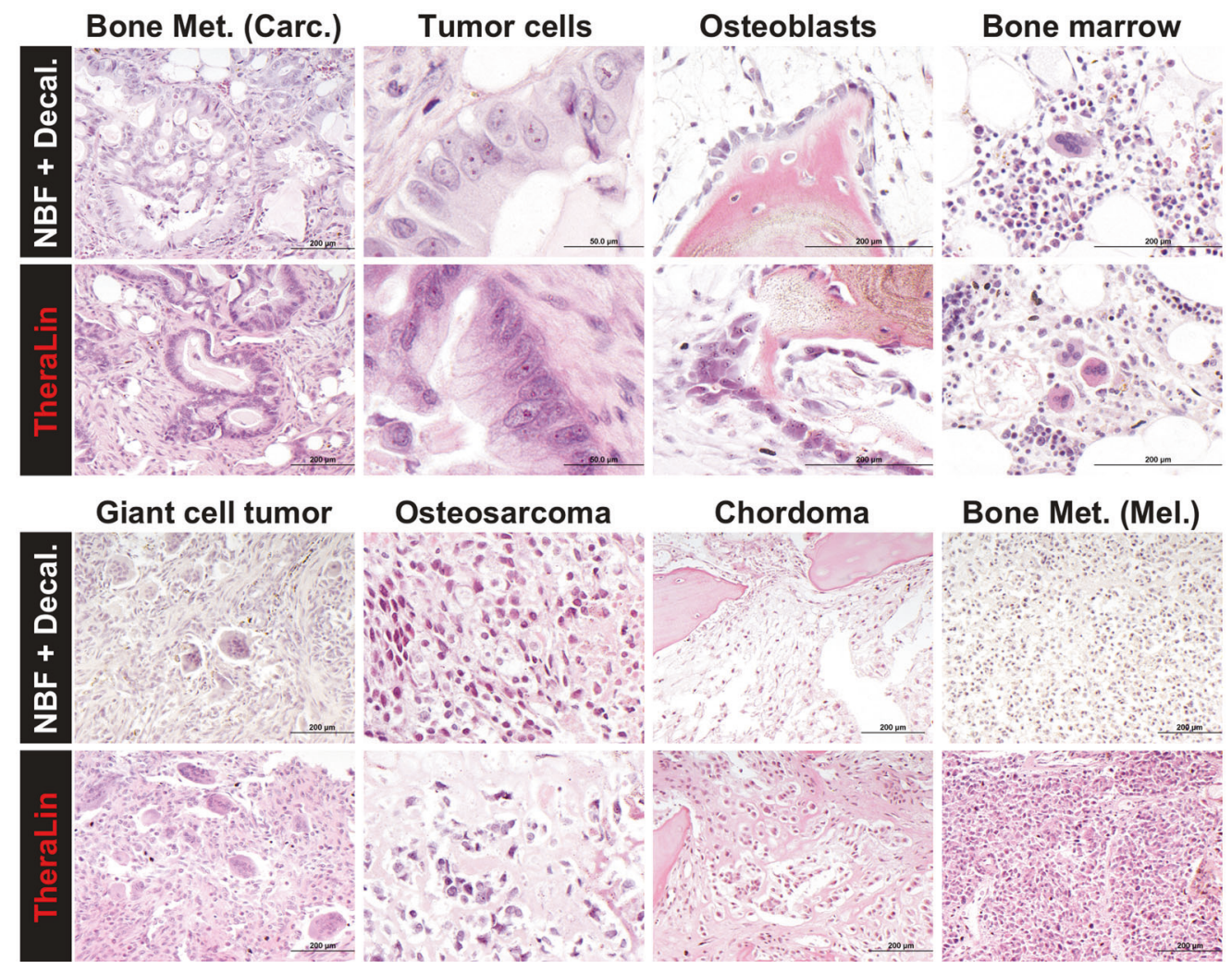

Bone Met. (Mel.)
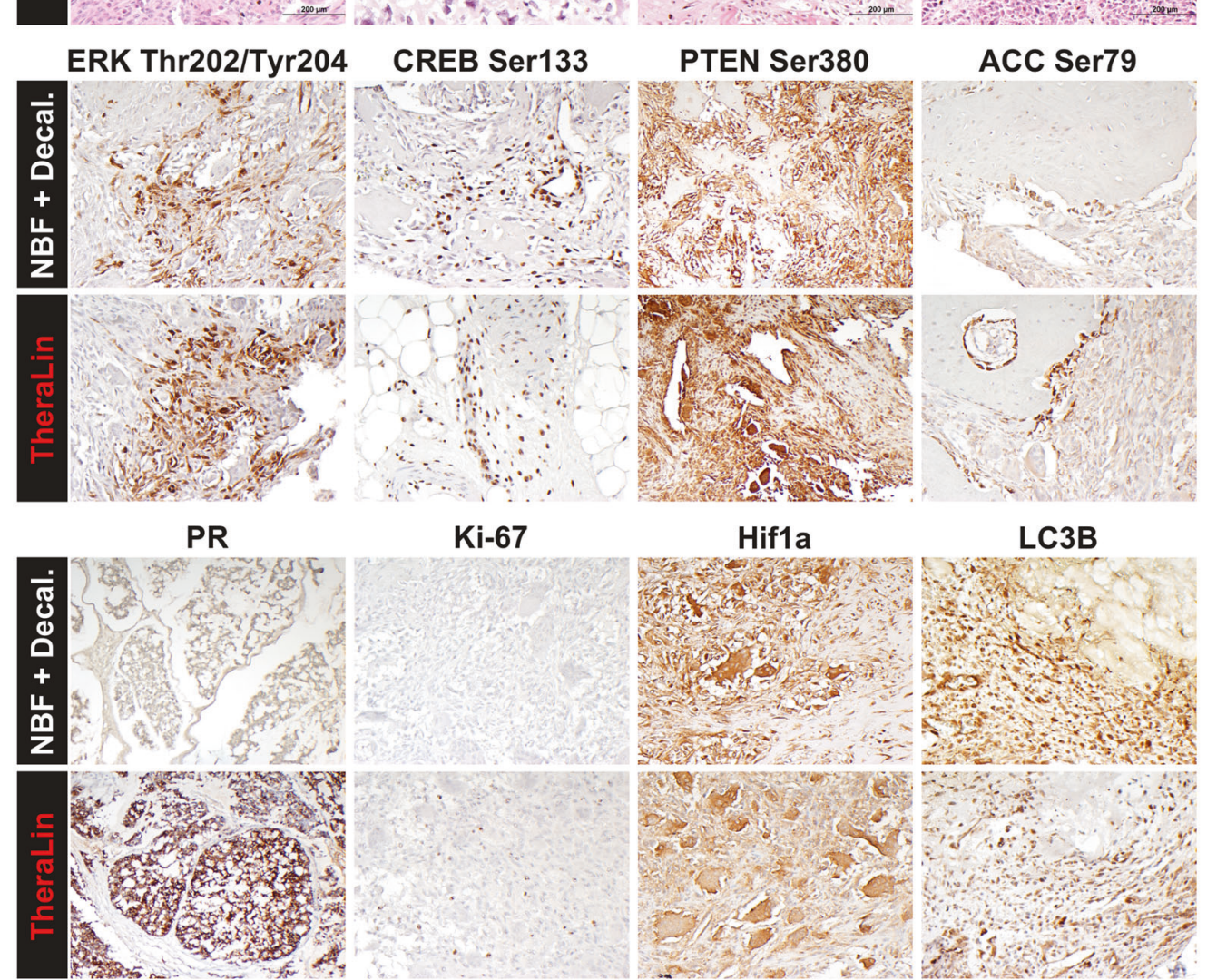

Ki-67
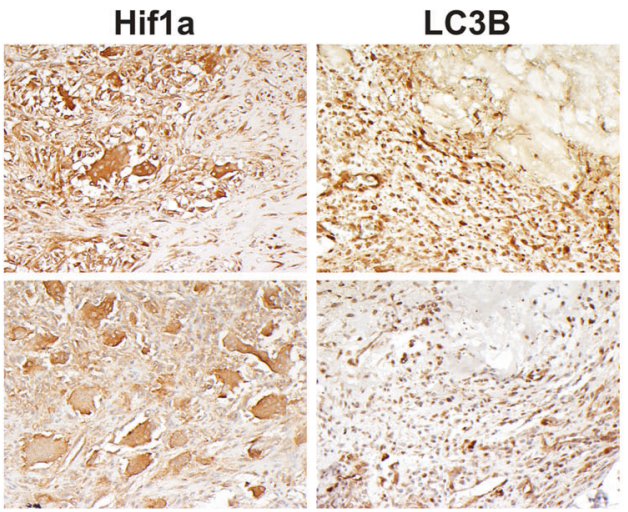

Fig. 3 Representative images comparing tissue morphology and IHC stains of theralin fixed and formalin fixed, decalcified bone tumor samples. Patient-matched tissue sections were stained with either hematoxylin and eosin (top half) or for selected IHC targets (bottom half) 


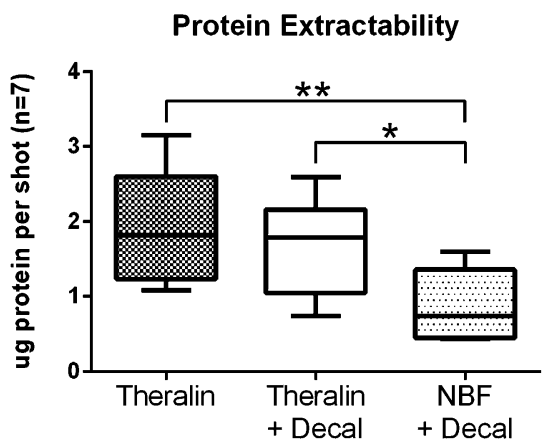

Fig. 4 Protein and DNA extractability is increased from theralin-fixed tissue. Patient matched bone tumor samples $(n=7)$ were either theralin fixed, theralin fixed and decalcified, or formalin fixed and decalcified. An equal number of tumor cells were laser-capture microdissected and cell lysates printed on reverse phase protein

out of seven cases. In contrast, theralin-fixed samples, either decalcified or not, clustered together in six out of seven cases (Fig. 6).

\section{Formalin fixation artifacts falsely elevate measured $\beta$-actin levels}

Both, $\beta$-Actin, and doublecortin, were found to be significantly increased in formalin fixed, decalcified tissue (Fig. 7a, Supplemental Fig. 1). This increase was independent of decalcification itself, as shown by comparing theralin fixed with theralin fixed and decalcified tissue (Fig. 7a, Supplemental Fig. 1). Because of its widespread use as loading control in western blot assays, we evaluated whether fixation time had any impact on $\beta$-Actin antibody recognition. Although time of fixation showed no effect for theralin fixed, non-decalcified tissue $\left(R^{2}=0.2, p>0.45\right), \beta$ actin levels did correlate with time of fixation in formalin $\left(R^{2}=0.8, p<0.05\right)$ (Fig. 7b). To determine whether this observation extends to other tissues and cells we fixed U266 cells in theralin or formalin for either $10 \mathrm{~min}$ or $2 \mathrm{~h}$. No difference in $\beta$-actin levels between theralin-fixed cells and non-fixed cells was found, whereas U266 cells fixed in formalin showed a significant increase in $\beta$-actin that was compounded by fixation time (Fig. 7c). Next, we fixed mouse liver for up to 7 days in either theralin or formalin and compared $\beta$-actin levels with frozen tissue. Theralinfixed tissue correctly represented $\beta$-actin levels independent of fixation time, whereas formalin-fixed tissue showed significantly falsely elevated levels of $\beta$-actin that were dependent on fixation time (Fig. 7d). Using a different antibody clone against $\beta$-actin showed the same trend of increased reactivity with increasing fixation time (Supplemental Fig. 1). Doublecortin reactivity was not dependent on fixation time for either of the two antibodies tested (Supplemental Fig. 1).

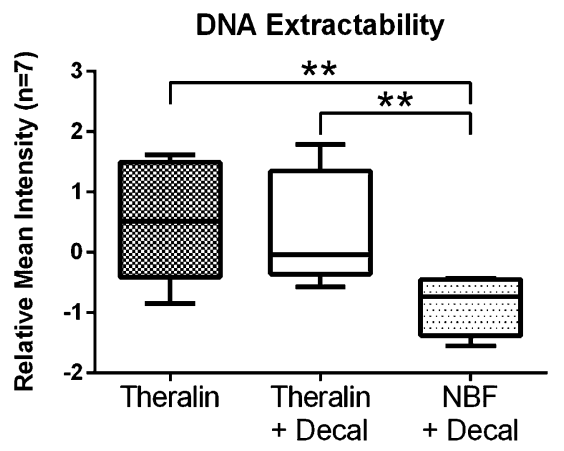

microarrays. Formalin fixation followed by decalcification yielded significantly less protein and DNA than theralin fixation with or without decalcification. (boxes $=25$ th to 75 th percentile with whiskers going to the smallest and largest value, Decal =decalcification, $\mathrm{NBF}=$ formalin fixation, $* p<0.05, * * p<0.005)$

\section{Theralin fixation enables FISH analysis in bone samples}

We next evaluated the impact of theralin fixation on downstream FISH. Seven osteosarcoma cases were selected, including three high-grade central, one low-grade central with areas of progression into high grade, one parosteal, and one periosteal osteosarcoma case, as well as a lymph node metastasis from a high grade central osteosarcoma. FISH staining was performed on theralin fixed, not-decalcified, and formalin fixed, decalcified samples, using one of two probes per case. The FOXO1 Dual Color Break-apart DNA probe is typically used to identify rearrangements of the chromosomal locus 13q14 that contains the FOXO1 gene, whereas the MDM2/CEN 12 Dual Color probe detects $M D M 2$ gene amplifications. Of the five theralin-fixed cases stained with the FOXO1 probe, two showed positive staining and three were negative (Fig. 8). None of the formalin-fixed, decalcified samples showed staining. Of the two theralin-fixed cases stained with $M D M 2 / C E N$, one was positive (central low grade, with areas of progression into high-grade osteosarcoma) and one negative (high grade central osteosarcoma). As before, no FISH staining was observed in patient matched formalinfixed, decalcified samples.

To limit any potential impact of tissue inhomogeneities in gene amplification or gene rearrangement between the patient matched sample blocks, we next selected two bone metastasis cases and hybridized sections with fluorochromecoupled (Cy3) Telomere PNA probes and counterstained with DAPI. No telomere staining was observed after formalin fixation and decalcification, whereas samples fixed with theralin without decalcification demonstrated clear telomere staining inside nuclei (Fig. 8). The same was observed for mouse rib and human tibia samples, with clear staining in theralin-fixed samples and no or significantly 


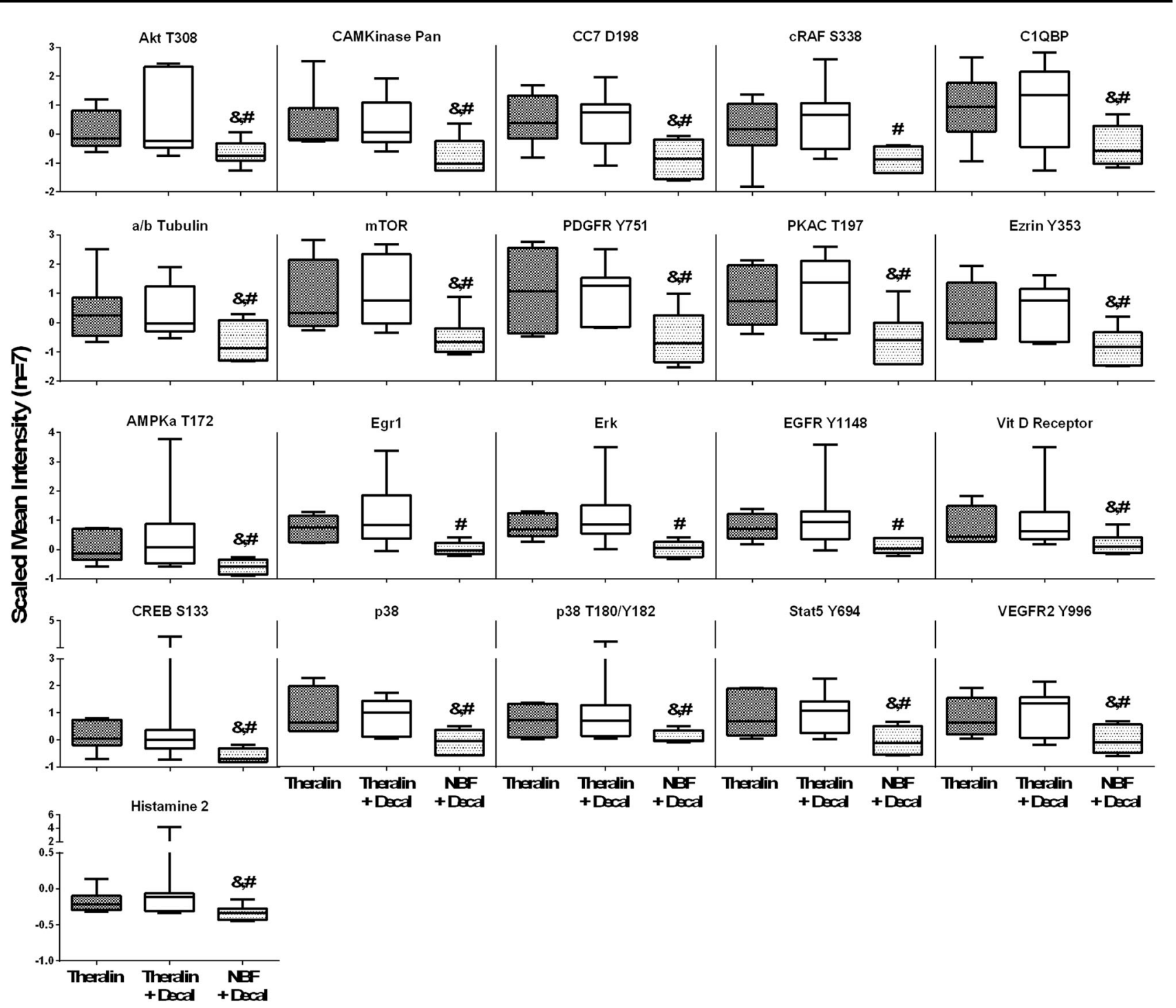

Fig. 5 The measurable protein level per microdissected tumor area is

laser-capture microdissected. Protein levels were measured using reverse phase protein microarrays and normalized to the microdissected area. (boxes $=25$ th to 75 th percentile with whiskers going to the smallest and largest value, ${ }^{\#} p<0.05$ versus theralin fixation, ${ }^{\circledR} p<$ 0.05 versus theralin fixation and decalcification)

reduced staining in formalin samples. We then stained a mouse liver sample that was fixed with formalin but not decalcified. Telomeres were clearly visible in this sample, indicating that it is the separate formic acid/nitric acid decalcification processing step that hinders FISH analysis.

\section{Discussion}

The objective of this study was to critically evaluate a novel fixative, theralin, for molecular profiling of bone tissue. Precision medicine is advancing asymmetrically, with analytical methods focusing on soft tissue and biofluids, whereas bone tissue is critically lagging behind [27].
Overcoming the critical hurdle that prohibits standard clinical assays such as FISH with bone specimens would immediately open an arsenal of already approved treatments and tests available to bone cancer patients. Likewise, unlocking bone for proteomics analysis is essential to identify the driver cell signaling pathways in bone cancer that can be targeted with currently available, or novel, kinase, and phosphatase inhibitors.

We developed a tissue-fixation chemistry, theralin, that maintains tissue histomorphology and posttranslationally modified proteins. Our serendipitous discovery that theralin simultaneously fixes and decalcifies bone tissue, which we attribute to the carboxylic acid component of the fixative, obviates the need for a separate decalcification step and 


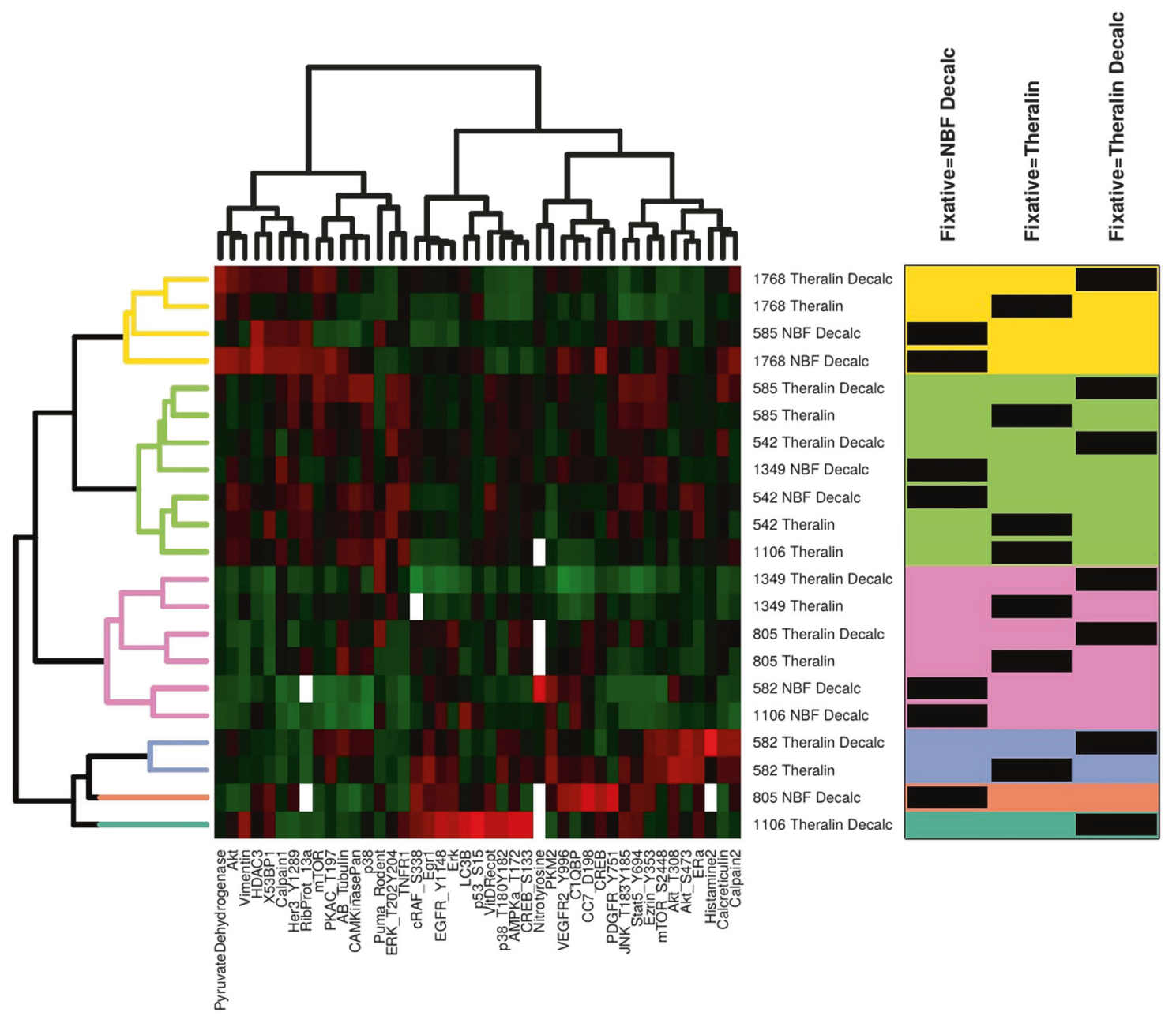

Fig. 6 Formalin fixed and decalcified samples cluster away from patient matched theralin fixed and theralin fixed and decalcified samples during two-way unsupervised hierarchical clustering. Tumor cells from seven patient matched samples that were either theralin fixed, theralin fixed and decalcified, or formalin-fixed and decalcified were laser-capture microdissected and lysates printed on reverse phase

therefore required evaluation of bony tissue. We have shown that theralin not only eliminates processing complexity, but also decreases sample processing time by an average of $23 \mathrm{~h}$. This is especially advantageous in a routine clinical setting, where samples from multiple different tissues need to be processed simultaneously. A significant number of bone samples demonstrated better quality morphology after theralin fixation ( $46 \%$ of samples), contrasting previous observations, where theralin-fixed tissues had equivalent, but not better, tissue morphology compared with standard formalin fixation [19]. This indicates that the main cause for the inferior quality morphology of formalin-fixed bone tissue was the required process of decalcification in formic/nitric acid, not the formalin fixation itself.

Formalin fixation is known to permanently cross-link amino groups [28], which requires incubating samples under reducing conditions at high temperature for extended protein microarrays. Relative protein levels were normalized to the total extracted protein content per sample owing to the reduced protein extractability from formalin fixed samples. Numbers in center column represent patient IDs. Box on right shows fixation type per sample (black bars) within each cluster (color shaded areas). (Decalc $=$ decalcified, $\mathrm{NBF}=$ formalin-fixed)

periods of time for adequate protein extraction [25, 29, 30]. This becomes a challenge when extracting proteins in small extraction buffer volumes $(<10 \mu \mathrm{l})$ from very small amounts of tissue, for example after LCM [31]. Using an adapted extraction protocol that was permissive for small buffer volumes following LCM, we found a twofold increase in protein yield from theralin-fixed tissue compared with formalin-fixed bone tissue. This was independent of downstream decalcification, as shown by the fact that even theralin-fixed and formic/nitric acid decalcified tissue had the same increase in protein yield compared with formalinfixed/decalcified tissue. This indicates that protein extractability is mainly dependent on the nature of the initial tissue fixation, which differs significantly between both fixatives. Although formalin fixation is based on permanently cross-linking biomolecules, Theralin is a precipitating fixative that contains reversible cross-linkers [19]. This 

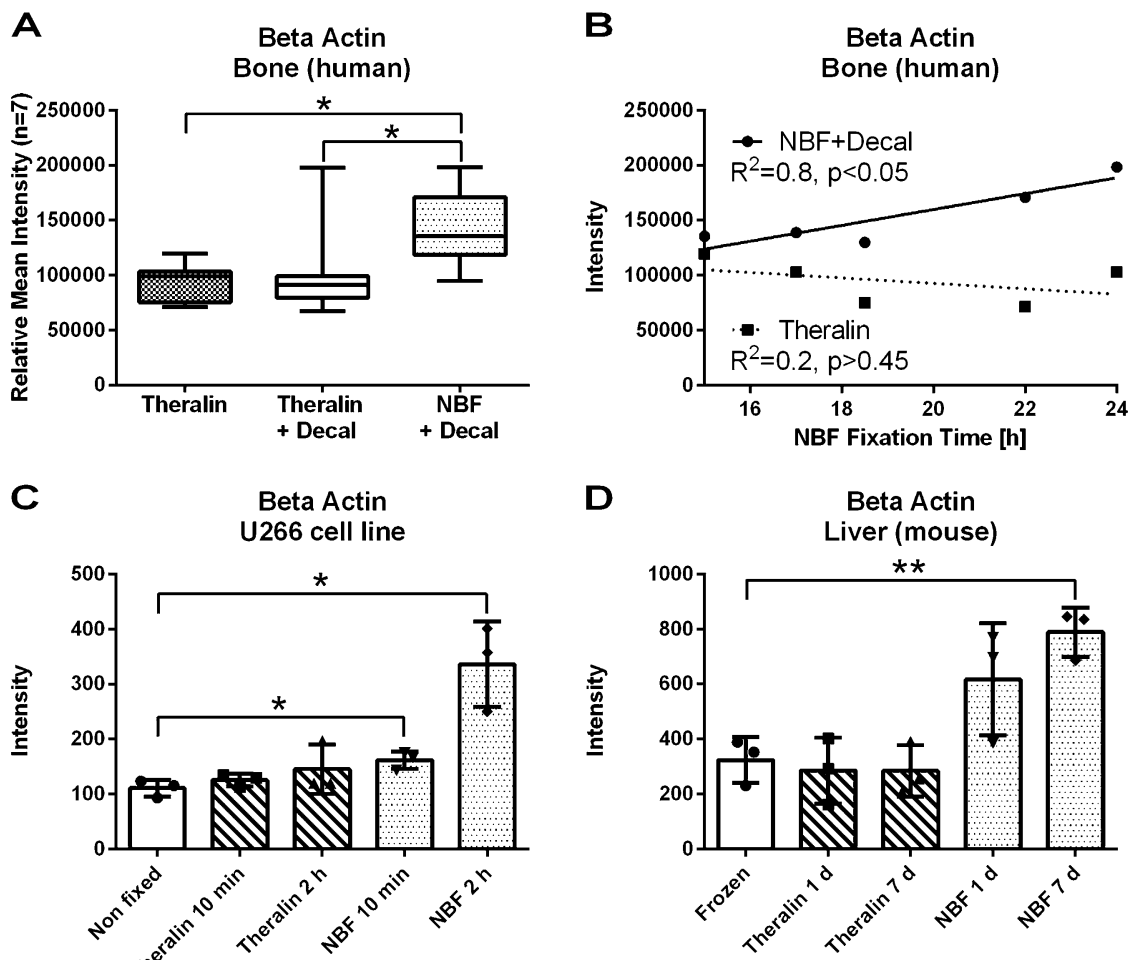

Fig. 7 Formalin fixation introduces a fixation artifact, whereby measurable $\beta$-actin levels correlate with fixation time. a $\beta$-actin is increased following formalin fixation and decalcification of bone tumor samples compared with theralin fixed or theralin fixed and decalcified patient matched samples $(n=7$, laser-capture microdissected tumor cells, boxes $=25$ th to 75 th percentile with whiskers going to the smallest and largest value, $* p<0.05)$. b Subset of patient samples from a where exact fixation times were available $(n=5)$ show a direct correlation between fixation time and the level of measurable $\beta$-actin

is further supported by our observation that proteins belonging to a very diverse set of classes were found to be reduced in formalin-fixed versus theralin-fixed samples. Of the 21 affected proteins (46\% of all proteins quantified), 11 were phosphorylated proteins, 9 were total proteins and one was a cleaved caspase (caspase 7), spanning different biochemical groups, such as cell surface receptors and receptor tyrosine kinases, cytosolic kinases and cleaved proteins, as well as different biological functions, such as apoptosis, cell growth, stress signaling and the cytoskeleton. No difference was found for any protein quantified between Theralin-fixed and formic/nitric acid decalcified samples versus just theralin-fixed samples.

We also found a threefold increase in DNA yield from theralin-fixed tissue compared with formalin-fixed bone tissue. However, it is important to point out that our data do not allow direct conclusions regarding the yield of nucleic acids from formalin-fixeddecalcified bone samples using nucleic acid specific isolation protocols. Rather, our methodological approach of cross-linking proteins and nucleic acids from whole-cell lysates directly to nitrocellulose slides

when fixed in formalin but not after theralin fixation. c Fixing U266 cells with formalin for either $10 \mathrm{~min}$ or $2 \mathrm{~h}$ causes an increase in measurable $\beta$-actin versus non-fixed cells. Theralin fixation does not alter $\beta$-actin levels, independent of fixation time $( \pm \mathrm{SD}, * p<0.05)$. d Fixing mouse liver with formalin for 1 day or 7 days increases measurable $\beta$-actin versus frozen tissue. Theralin fixation kept $\beta$-actin levels at frozen tissue levels irrespective of fixation time $( \pm \mathrm{SD}, * p<$ $0.01)$

is specific to and critical for reverse phase protein microarray analysis and allows data normalization with DNA content per sample [23]. We have previously described the advantages of using DNA for protein level normalization purposes, especially in the context of bone marrow aspirates that are contaminated with blood [23]. Although the protein contribution by erythrocytes can skew total protein levels within a sample, their lack of a nucleus makes DNA normalization largely blind to the highly variable presence of erythrocytes [23]. Quantifying low-abundance biomolecules therefore requires significantly less material from theralinfixed bone tissue compared with formalin-fixed, decalcified samples. Low-abundance proteins are a significant source of cancer-specific biomarkers [32], and the improved sensitivity of protein detection described here will help to unlock the proteomic archive of bone tissue.

Improper formalin fixation can lead to artifacts in tissue morphology [16, 33, 34]. For example, fixed tissue can shrink, causing empty spaces between formerly attached tissue areas, biomolecules can diffuse out of the fixed tissue [34], and pigments can form, interfering with the 
Human Osteosarcoma (FOX01)

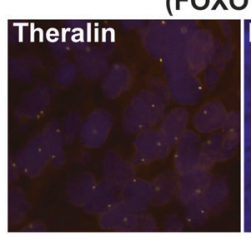

Human Tibia

(Telomere)

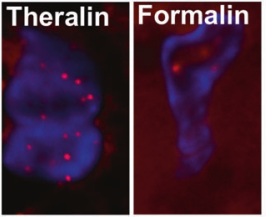

Human Bone Metastasis 1

(Telomere)

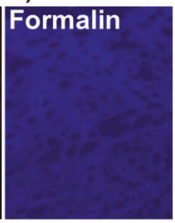

Mouse Ribs

(Telomere)

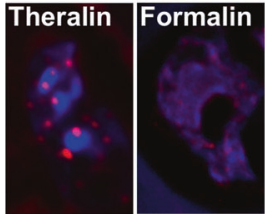

Mouse Liver

(Telomere)

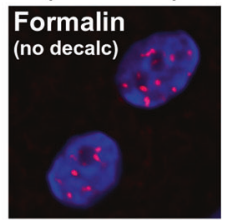

Human Bone Metastasis 2

(Telomere)

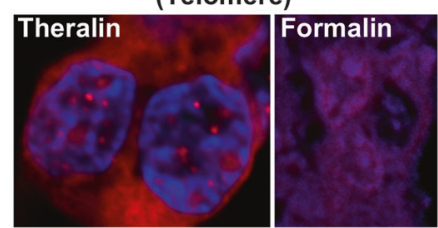

Fig. 8 Theralin fixation enables FISH staining in bone tissue. Top panel: representative images of patient matched, theralin fixed or formalin-fixed, decalcified, human bone tumor samples that were stained with a probe for FOXO1 or telomeres. Theralin-fixed samples demonstrate clear FISH staining, whereas formalin-fixed, decalcified samples are non-interpretable. Bottom panel: representative images of mouse bone samples that were fixed with theralin or formalin +

interpretation of IHC stains. In addition, formalin fixation can lead to a falsely elevated identification of DNA mutations owing to the introduction of random base damage along templates [35]. Here, we have identified an additional formalin fixation artifact that has significant implications for proteomic data quantification. We have shown that fixation time in formalin, but not theralin, directly correlates with $\beta$ actin levels. Formaldehyde cross-links biomolecules first at reactive sites composed of amines, purines, and thiols, followed by the formation of methylene bridges that involve amides, asparagines and guanidine and tyrosine carbon rings [36]. The number of cross-links increases with time and may take up to 30 days to finalize [36]. This has significant implications for proteins with repetitive motifs or proteins, such as $\beta$-actin, that polymerize to form long filaments. Antibodies that are generated to specifically bind cross-linked protein epitopes will "see" more of said protein as fixation time and cross-linking increases. We believe that this effect is causing the correlation of $\beta$-actin levels with formalin fixation time that we observed here. Antibody vendors typically do not share the exact procedure for antibody creation and the pre-processing or the sequence of the antigenic peptides used. It therefore becomes critical to ensure equal formalin fixation times for samples within a study if the downstream analysis includes relative protein quantification. However, in a clinical environment, this is very difficult to achieve. Theralin did not alter detectable protein levels with increased fixation time, which supports its use as an alternative fixative for formalin if the study goal includes protein quantification from clinical samples.

We also measured a significantly increased level of Doublecortin in formalin-fixed versus theralin-fixed decalcification and stained for telomeres. In addition, a mouse liver was fixed with formalin without decalcification and stained for telomeres. The positive stain indicates that the formic acid/nitric acid decalcification process is the cause for lack of staining in formalinfixed, decalcified bone samples. Telomere images shown here depict a region of interest zooming onto one or two single nuclei to visualize the telomere signals in red

samples (Supplemental Fig. 1). At this time, it is unclear whether both of the antibodies that were tested preferentially bind formalin cross-linked Doublecortin, which do not polymerize into long filaments and should therefore not benefit from longer formalin fixation times, or if Doublecortin is better preserved in formalin-fixed samples. Future studies will have to address this question.

A significant percentage of primary breast tumors and their metastases show discordance in their estrogen, progesterone and HER2 receptor status [18, 37-41], with previously reported discordance rates of 7-54, 20-54, and $3-33 \%$, respectively. Routinely determining the receptor status of bone metastases could significantly change patient management, as demonstrated in a pilot study, where $20 \%$ of breast cancer patients received altered care from their primary physician after including IHC/FISH diagnosis of bone metastases [41]. Although regular IHC can be performed on bone tissue, FISH will not work after standard acid decalcification. Therefore, HER2 FISH, which is the current gold standard in HER2 receptor status determination, has to be done on non-decalcified core biopsies [41]. But, depending on the site of metastasis, this is generally not practicable. Another alternative is biopsy decalcification with EDTA, which has shown promising preservation of DNA for FISH in selected studies [11, 42]. In fact, one previous study compared HER2 FISH with IHC in breast cancer bone metastasis samples that were decalcified with EDTA, finding high concordance between both methods [43]. However, a major disadvantage of decalcification with EDTA is its slow action, requiring several days to weeks with regular solution replacement, even when supporting the process by constant oscillation or ultrasonic baths $[42$, 
43]. The fixation technology described here enables rigorous, fast, and standardized clinical IHC and FISH assays to be routinely performed on bone tissue samples.

Interestingly, of the two osteosarcoma cases that were stained with $M D M 2 / C E N$, only the central low grade osteosarcoma with areas of progression into high grade showed positive staining. MDM2, which is frequently amplified in low grade, but not high grade osteosarcoma, is a sensitive and specific marker in combination with CDK4 for the subclass of high-grade osteosarcomas that have progressed from low-grade osteosarcomas [44-46].

Enabling FISH analysis for bone tissue is of special concern for breast cancer patients, because bone is a primary metastatic site for breast cancer, regardless of the breast cancer subtype [6]. There is an unknown proportion of women who harbor HER2-positive bone metastasis but cannot receive efficacious anit-HER2 therapy because HER2 FISH will not work after standard acid decalcification and formalin fixation. We propose that using theralin for bone tissue preservation meets this critical need because it unlocks decalcified bone tissue for FISH analysis while maintaining the performance of standard IHC. Processing bone tumor samples with theralin or formalin showed comparable overall results for $125 \mathrm{IHC}$ stains in a regular clinical diagnostics laboratory setting. This is in agreement with previous results, where fixation of soft tissue with theralin maintains or enhances staining of key cancer diagnostic IHC antigens, including Ki-67, estrogen receptor alpha, and progesterone receptor [19]. HER2 protein epitopes were preserved exceptionally well for IHC in theralinfixed breast tumor samples [19]. Although the current data demonstrate that theralin fixation enables FISH in bone tissue, this study set consisted primarily of primary bone tumors and therefore did not permit us to specifically evaluate HER2 FISH analysis in a breast metastasis setting. A future study will have to evaluate the concordance of HER2 FISH results obtained after using the fixation technology described here and standard buffered formalin, according to published ASCO and CAP guidelines [47, 48].

In conclusions, we have developed a tissue fixation chemistry, theralin, that simultaneously fixes and decalcifies bone tissue, obviating the need for a separate decalcification step while improving tissue histomorphology for diagnosis. Theralin fixation significantly shortens the time necessary for tissue processing and eliminates the processing step that hinders FISH in bone. Thus, the use of theralin enables routine FISH analysis in bone. Furthermore, theralin greatly enhances the extractability of protein and DNA from bone samples, which significantly reduces the necessary tissue input necessary for downstream applications. In addition, theralin overcomes a serious formalin fixation artifact, whereby the measured quantity of repetitive proteins such as $\beta$-actin depends directly on fixation time, preventing comparison between tissues with different formalin fixation times. This has significant implications for antibody based proteomic methods that may depend on normalization by a "housekeeping" protein such as $\beta$-actin.

A weakness of the present study is that a relatively low number of cases was distributed among many different types of bone cancer rather than a large sample size of any one individual type of cancer. We used this diverse sample set to test a range of diagnostic biomolecules and analysis technologies that are known to be impacted by bone processing methods. The data presented here provide strong justification that our fixative technology is of general utility by improving tissue histomorphology and phosphoprotein analysis, and enabling FISH. Based on this foundation, we can now apply this fixative in clinical trials for investigating the discordance between primary tumor and bone metastasis in tumor types with high prevalence of bone metastases (i.e., breast cancer), or assessing drug efficacy in bony tissue, as well as discovering biomarkers in bony tissue.

Acknowledgements We thank Jennifer Freeland, Sharmini Muralitharan, and Haiping Liu for their helpful guidance and discussions regarding FISH protocols. This work was supported in part by George Mason University, Inova Fairfax Hospital, Rizzoli Orthopedic Institute, and two National Institutes of Health grants to LAL (R21CA125698-01A1 and R33CA157403-01) from the National Cancer Institute program "Innovations in cancer cample preparation".

\section{Compliance with ethical standards}

Conflict of interest LAL and VE are inventors of the fixation technology and, as university employees, may receive patent royalties per university policies related to US patent $8,460,859$ B2: Tissue preservation and fixation method.

Publisher's note: Springer Nature remains neutral with regard to jurisdictional claims in published maps and institutional affiliations.

\section{References}

1. Mosialou I, Shikhel S, Liu J-M, et al. MC4R-dependent suppression of appetite by bone-derived lipocalin 2. Nature. 2017;543:385-90.

2. Lee NK, Sowa H, Hinoi E, et al. Endocrine regulation of energy metabolism by the skeleton. Cell. 2007;130:456-69.

3. Ferron M, Wei J, Yoshizawa T, et al. Insulin signaling in osteoblasts integrates bone remodeling andenergy metabolism. Cell. 2010;142:296-308.

4. Bhattacharyya N, Chong WH, Gafni RI, Collins MT. Fibroblast growth factor 23: state of the field and future directions. Trends Endocrinol Metabol. 2012;23:610-8.

5. Mundy GR. Metastasis to bone: causes, consequences and therapeutic opportunities. Nat Rev Cancer. 2002;2:584-93.

6. Wu Q, Li J, Zhu S, et al. Breast cancer subtypes predict the preferential site of distant metastases: a SEER based study. Oncotarget. 2017;8:27990-6.

7. Morris RE, Benton RS. Studies on demineralization of bone. I. The basic factors of demineralization. Am J Clin Pathol. 1956;26:579-95. 
8. Morris RE, Benton RS. Studies on demineralization of bone. II. The effect of electrolytic technics in demineralization. Am J Clin Pathol. 1956;26:596-603.

9. Morris RE, Benton RS. Studies on demineralization of bone. III. The effect of ion exchange resins and versenate in demineralization. Am J Clin Pathol. 1956;26:771-7.

10. Walsh L, Freemont AJ, Hoyland JA. The effect of tissue decalcification on mRNA retention within bone for in-situ hybridization studies. Int J Exp Pathol. 1993;74:237-41.

11. Alers JC, Krijtenburg P-J, Vissers KJ, van Dekken H. Effect of bone decalcification procedures on DNA in situ hybridization and comparative genomic hybridization: EDTA is highly preferable to a routinely usedacid decalcifier. J Histochem Cytochem. 1999;47:703-9.

12. Bass BP, Engel KB, Greytak SR, Moore HM. A review of preanalytical factors affecting molecular, protein, and morphological analysis of formalin-fixed, paraffin-embedded (FFPE) tissue: how well do you know your FFPE specimen? Arch Pathol Lab Med. 2014;138:1520-30.

13. Case NM. The use of a cation exchange resin in decalcification. Stain Technol. 1953;28:155-8.

14. Cleland TP, Vashishth D. Bone protein extraction without demineralization using principles from hydroxyapatite chromatography. Anal Biochem. 2015;472:62-6.

15. Morris RE, Benton RS, Smith L, Haskins J. Studies on demineralization of bone: IV. Evaluation of morphology and staining characteristics of tissues after demineralization. Am J Clin Pathol. 1956;26:882-98.

16. Bindhu P, Krishnapillai R, Thomas P, et al. Facts in artifacts. J Oral Maxillofac Pathol. 2013;17:397-401.

17. Broxterman HJ, Georgopapadakou NH. New cancer therapeutics: target-specific in, cytotoxics out? Drug Resist Updat. 2004;7:79-87.

18. Perez-Fidalgo JA, Eroles P, Ferrer J, et al. An evaluation of the impact of technical bias on the concordance rate between primary and recurrent tumors in breast cancer. Breast. 2013;22:974-9.

19. Mueller C, Edmiston KH, Carpenter C, et al. One-step preservation of phosphoproteins and tissue morphology at room temperature for diagnostic and research specimens. PLoS ONE. 2011;6:e23780.

20. Skinner RA, Hickmon SG, Lumpkin CK, et al. Decalcified bone: twenty years of successful specimen management. J Histotechnol. 1997;20:267-77.

21. Gallagher RI, Blakely SR, Liotta LA et al. Laser Capture Microdissection: ArcturusXT Infrared Capture and UV Cutting Methods. In Methods in Molecular Biology: NY, USA, Humana Press) 157-78, 2011.

22. Mueller C, Liotta LA, Espina V. Reverse phase protein microarrays advance to use in clinical trials. Mol Oncol. 2010;4:461-81.

23. Chiechi A, Mueller C, Boehm KM, et al. Improved data normalization methods for reverse phase protein microarray analysis of complex biological samples. BioTechniques. 2012;0:1-7.

24. R Core Team. R: A Language and Environment for Statistical Computing. (Vienna, Austria: R Foundation for Statistical Computing, 2012).

25. Becker KF, Schott C, Hipp S, et al. Quantitative protein analysis from formalin-fixed tissues: implications for translational clinical research and nanoscale molecular diagnosis. J Pathol. 2007;211:370-8.

26. Espina V, Mariani BD, Gallagher RI, et al. Malignant precursor cells pre-exist in human breast DCIS and requireautophagy forsurvival. PLoS One. 2010;5:e10240.

27. Bhattacharyya S, Byrum S, Siegel ER, et al. Proteomic analysis of bone cancer: a review of current and future developments. Expert Rev Proteom. 2007;4:371-8.
28. Kiernan JA. Formaldehyde, formalin, paraformaldehyde and Glutaraldehyde: what they are and what they do. Microsc Today. 2000;8:8-13.

29. Becker K-F, Mack H, Schott C, et al. Extraction of phosphorylated proteins from formalin-fixed cancer cells and tissues. Open Pathol J. 2008;2:46-52.

30. Ostasiewicz P, Zielinska DF, Mann M, et al. Proteome, phosphoproteome, and $\mathrm{N}$-glycoproteome are quantitatively preserved in formalin-fixed paraffin-embedded tissue and analyzable by highresolution mass spectrometry. J Proteome Res. 2010;9:3688-700.

31. Emmert-Buck MR, Bonner RF, Smith PD, et al. Laser capture microdissection. Science. 1996;274:998-1001.

32. Byrum S, Montgomery CO, Nicholas RW, et al. The promise of bone cancer proteomics. Ann N Y Acad Sci. 2010;1192:222-9.

33. Chatterjee S. Artefacts in histopathology. J Oral Maxillofac Pathol. 2014;18:S111-6.

34. Khan S, Tijare M, Jain M, et al. Artifacts in histopathology: a potential cause of misinterpretation. Res Rev J Dent Sci. 2014;2:23-31.

35. Quach N, Goodman MF, Shibata D. In vitro mutation artifacts after formalin fixation and error prone translesion synthesis during PCR. BMC Clin Pathol. 2004;4:1.

36. Thavarajah R, Mudimbaimannar VK, Elizabeth J. et al. Chemical and physical basics of routine formaldehyde fixation. J Oral Maxillofac Pathol. 2012;16:400-5.

37. Ibrahim MF, Hilton J, Addison C, et al. Strategies for obtaining bone biopsy specimens from breast cancer patients - past experience and future directions. J Bone Oncol. 2016;5:180-4.

38. Amir E, Ooi WS, Simmons C, et al. Discordance between receptor status in primary and metastatic breast cancer: an exploratory study of bone and bone marrow biopsies. Clin Oncol (R Coll Radiol). 2008;20:763-8.

39. Amir E, Miller N, Geddie W, et al. Prospective study evaluating the impact of tissue confirmation of metastatic disease in patients with breast cancer. J Clin Oncol. 2012;30:587-92.

40. Aurilio G, Monfardini L, Rizzo S, et al. Discordant hormone receptor and human epidermal growth factor receptor 2 status in bone metastases compared to primary breast cancer. Acta Oncol. 2013;52:1649-56.

41. Simmons C, Miller N, Geddie W. et al. Does confirmatory tumor biopsy alter the management of breast cancer patients with distant metastases?. Ann Oncol. 2009;20:1499-504.

42. Neat MJ, Moonim MT, Dunn RG, et al. Fluorescence in situ hybridisation analysis of bone marrow trephine biopsy specimens; an additional tool in the diagnostic armoury. J Clin Pathol. 2013;66:54-57.

43. Zustin J, Boddin K, Tsourlakis MC. et al. HER-2/neu analysis in breast cancer bone metastases. J Clin Pathol. 2009;62:542-6.

44. Righi A, Gambarotti M, Benini S. et al. MDM2 and CDK4 expression in periosteal osteosarcoma. Hum Pathol. 2015;46:549-53.

45. Dujardin F, Binh MB, Bouvier C. et al. MDM2 and CDK4 immunohistochemistry is a valuable tool in the differential diagnosis of low-grade osteosarcomas and other primary fibro-osseous lesions of the bone. Mod Pathol. 2011;24:624-37.

46. Yoshida A, Ushiku T, Motoi T, et al. MDM2 and CDK4 immunohistochemical coexpression in high-grade osteosarcoma: correlation with a dedifferentiated subtype. Am J Surg Pathol. 2012;36:423-31.

47. Wolff AC, Hammond ME, Schwartz JN. American Society of Clinical Oncology/College of American Pathologists guideline recommendations for human epidermal growth factor receptor 2 testing in breast cancer. J Clin Oncol. 2007;25:118-45.

48. Hanna W, O'Malley FP, Barnes P, et al. Updated recommendations from the Canadian National Consensus Meeting on HER2/ neu testing in breast cancer. Curr Oncol. 2007;14:149-53. 